\title{
KEPEMIMPINAN PENDIDIKAN ISLAM DI SD SALSABILA 3 BANGUNTAPAN
}

\author{
Ichsan Mubaedi \\ PascasarjanaUIN Sunan Kalijaga Yogyakarta \\ e-mail:imubaedi5@gmail.com
}

\begin{abstract}
Abstrak
Kepala sekolah SDIT Salsabila 3 Banguntapan, Yogyakarta telah melakukan beberapa tugasnya sebagai seorang pemimpin. Seperti menerapkan kebijakan, menyelesaikan tugas dan tanggung jawab, serta keputusan-keputusan lainnya. Sebagai kepala sekolah, Ia telah menerapkan kebijakan dan menjalankan tanggung jawabnya sesuai dengan kebutuhan sekolah. Bentuk dari semua yang dilakukannya merupakan cerminan dari pendidikan Islam. Penjabaran dalam pendidikan Islam sendiri sebenarnya masih sangat luas, namun diantaranya menyangkut persoalan kepemimpinan. Sedangkan, kepemimpinan yang baik, salah satunya sudah dilakukan oleh kepala sekolah SDIT 3 Banguntapan.
\end{abstract}

Kata Kunci: kepala sekolah, pendidikan Islam, kepemimpinan

\section{A. Pendahuluan}

Manusia dikenal sebagai makhluk sosial yang berarti bahwa manusia saling membutuhkan didalam kehidupannya. Rasa butuh inilah yang menyebabkan adanya sebuah interaksi, kerjasama, komunikasi, dan hidup secara bersamasama. Manusia, karena rasa sosialnya juga memiliki kecenderungan untuk membuat komunitas, hidup berkelompok-kelompok di suatau wilayah tertentu sesuai dengan kesamaan sifat, latarbalakang maupun tujuannya. Dalam suatu komunitas, ada semacam naluri untuk menghadirkan sebuah pemimpin ditangah-tengah mereka. ${ }^{1}$ Hal ini dipandang dapat membantu sebuah 
efisiensi kerja dalam mencapai sebuah tujuan bersama, mempertahankan kehidupan bersama, kesolidan, dan kooperatif yang sangat diperlukan dalam keberlangsungan kepentingan kelompok, maka dari itu diperlukanya sebuah pemimpin. Selain masalah itu, komunitas juga cenderung untuk memiliki sebuah panutan, yakni sosok yang dianut, dianggap mamapu melindungi dan mengayomi mereka, serta bisa diandalkan untuk sebuah diplomasi dengan kelompok lain. Kepemimpinan mempunyai arti bimbingan, menuntun, mengarahkan dan berjalan didepan. Pemimpin berperilaku untuk membantu organisasi secara maksimal untuk mencapai sebuah tujuan. Pemimpin haruslah bisa memberi contoh, tauladan ketika dia berada di depan (ing ngarsa sang tuladha). Pemimpin haruslah memberikan motivasi, mengayomi, memberi semangat, melindungi ketika dia berada ditengah (ing madya mangun karsa). Dan pemimpin haruslah bisa mendorong anggotanya untuk maju, unggul dalam mencapai tujuan, ketika dia berada di belakang (tut wuri handayani). ${ }^{2}$

Sebuah kepemimpinan tidak hanya dibutuhkan dalam dunia sosial, perusahaan, ataupun sebuah ketatanegaraan. Tapi kepemimpinan juga mutlak dibutuhkan dalam dunia pendidikan. Profesionalisme dan standarisasi didalam sebuah dunia pendidikan merupakan hal yang harus dipenuhui untuk saat ini, dikarenakan tuntutan zaman yang semakin kompleks. Tercapainya sebuah tujuan pendidikan sangat tergantung dengan bagaimana sebuah pelaksanaan kepemimpinan disuatu sekolah, yang merupakan ujung tombak dari sistem pendidikan.

Keberhasilan atau kegagalan suatu sekolah dalam menampilkan kinerjanya banyak bergantung pada kualitas kepemimpinan kepala sekolah. Kualitas kepemimpinan kepala sekolah sendiri ditentukan oleh bagaimana kompetensi yang dimiliki, keterampilan manajerial yang dikuasai, dan gaya kepemimpinan yang sesuai dengan kondisi sekolah terutama tingkat kematangan dan tanggung jawab guru dalam menjalankan tugas pendidikan dan pembelajaran di sekolah.

Dalam mempelajari kepemimpinan sekolah tidak hanya cukup lewat teori-teori saja, tapi juga dibutuhkan sebuah pengamatan langsung didalam sebuah sekolah. Untuk itu, peneliti mengadakan sebuah penelitian tentang bagaimana kepemimpinan yang ada di dalam SD Salsabila 3 Banguntapan. 


\section{B. Metode penelitian}

Jenis penelitian ini adalah Penelitian kualitatif dengan menerapkan metode pendekatan struktural fungsional, yakni interpretasi terhadap masyarakat yang dinyatakan sebagai suatu sistem yang memiliki struktur yang terdiri dari banyak lembaga dimana masing-masing lembaga memiliki fungsi sendiri-sendiri. ${ }^{1}$

Adapun subyek dalam penelitian ini adalah Kepala SD Salsabila 3 Banguntapan dan semua pihak yang ikut berkontribusi dalam penelitian ini. Sedangkan yang menjadi obyek penelitian adalah terkait kepemimpinan yang dilakukan oleh kepala sekolah beserta dengan aturan atau semua yang berkaitan dengan kegiatan SD Salsabila 3 Banguntapan.

Untuk memperoleh data yang benar dan dapat dipercaya serta sesuai dengan persoalan yang dihadapi maka diperlukan beberapa metode yaitu observasi, wawancara, dan dokumentasi. Metode observasi ini digunakan untuk mendapatkan data tentang gambaran umum mengenai SD Salsabila 3 Banguntapan. Metode wawancara ini digunakan untuk mendapatkan informasi mengenai kepmimpinan pendidikan Islam di SD Salsabila 3 Banguntapan. Adapun yang menjadi sasaran metode ini adalah kepala SD Salsabila 3 Banguntapan. Dimana daftar pertanyaannya tidak terlepas dari pedoman interview guide yang telah dipersiapkan. Dan terakhir metode dokumentasi digunakan untuk memperoleh data yang lebih detail dan terperinci yang tidak dapat diungkap dengan metode-metode lain. Dalam hal ini yang dijadikan sumber dokumentasi bagi peneliti adalah buku-buku yang terkait dengan teori-teori kepemimpinan pendidikan Islam.

Penelitian ini menggunakan analisis kualitatif sehingga kesimpulan dari fakta-fakta yang bersifat khusus ke fakta-fakta yang bersifat umum. Selain itu juga menggunakan "Triangulasi", yaitu penggabungan metode. ${ }^{2}$ Dalam hal ini penggabungan antara wawancara dengan dokumentasi. Data hasil wawancara akan dibandingkan dengan kesesuaian data dokumentasi. Dengan

Zamroni, Pengantar Pengembangan Teori Sosial, (Yogyakarta: Tiara Wacana, 1992), 25.

2 Burhan Bungin, Penelitian Kualitatif: Komunikasi, Ekonomi, Kebijakan Publik, dan Ilmu Sosial Lainnya, (Jakarta: Kencana, 2008), 249. 
demikian dapat diketahui kepemimpinan pendidikan Islam di SD Salsabila 3 Banguntapan.

\section{Hasil Penelitian dan Pembahasan}

\section{A. Pengertian Kepemimpinan}

Kepemimpinan merupakan salah satu faktor yang sangat penting dalam suatu organisai karena sebagian besar keberhasilan dan kegagalan suatu organisasi ditentukan oleh kepemimpinan dalam organisasi tersebut. Menurut beberapa tokoh, kepemimpinan adalah :

1. James M. Black: “Kepemimpinan adalah kemampuan meyakinkan dan menggerakkan orang lain agar mau bekerja sama di bawah kepemimpinannya sebagai suatu tim untuk mencapai suatu tujuan tertentu

2. Maman Ukas: "Kepemimpinan adalah kemampuan yang dimiliki oleh seseorang untuk dapat mempengaruhi orang lain, agar ia mau berbuat sesuatu yang dapat membantu pencapaian suatu maksud dan tujuan"

3. Ordway Tead: "kegiatan mempengaruhi orang-orang agar mereka mau bekerjasama untuk mencapai tujuan yang diinginkan.

4. Howard H. Hyot:" kepemimpinan adalah seni untuk mempengaruhi tingkah laku manusia, kemampuan untuk membimbing orang lain

5. George R. Terry: "Kepemimpinan adalah aktivitas untuk mempengaruhi orang-orang supaya diarahkan mencapai tujuan organisasi”.

6. Robert G. Ownes: kepemimpinan adalah keterlibatan yang dilakukan secara sengaja untuk mempengaruhi orang lain ${ }^{3}$

Berdasarkan beberapa definisi tersebut dapat disimpulkan bahwa kepemimpinan adalah kemampuan yang dimiliki seseorang dalam mempangaruhi orang lain untuk mau bekerjasama agar mau melakukan

Wahyudi, Kepemimpinan Kepala Sekolah:Dalam Organisasi Pembelajar, (Bandung: Alfabeta, 2009), hal. 120 
tindakan dan perbuatan dalam mencapai tujuan bersama. ${ }^{4}$

Sebuah kepemimpinan mempunyai prasyaratan tertentu yang dikaitkan dengan tiga hal penting yaitu: ${ }^{5}$

1. Kekuasaan adalah kekuatan, otoritas dan legalitas yang memberikan wewenang kepada pemimpin guna mempengaruhi bawahan untuk berbuat sesuatu

2. Kewibawaan ialah kelebihan, keunggulan, keutamaan sehingga orang mampu mengatur orang lain

3. Kemampuan ialah segala daya, kesanggupan, kekuatan dan kecakapan teknis maupun sosial, dibanding dengan orang lain

Sesorang pemimpin dalam menjalankan kepemimpin haruslah efektif, maka dari itu pemimpin haruslah mempunyai sifat-sifat antara lain: ${ }^{6}$

1. Stamina yaitu kemampuan bertahan dan tidak mudah menyerah

2. Pengikut

3. Energi

4. Kecakapan

5. Kecerdasan

6. Karakter

7. Berpikiran bersih dan jujur

8. simpati

\section{B. Pengertian Pemimpin}

Pemimpin sendiri memiliki kaitan erat dengan kepemimpinan. Beberapa ahli mendefenisikan pemimpin diantaranya:

1. Malayu S.P. Hasibuan, Pemimpin adalah seseorang dengan wewenang kepemimpinannya mengarahkan bawahannya untuk mengerjakan sebagian dari pekerjaannya dalam mencapai tujuan.

\footnotetext{
4 Oteng sutisna, Administrasi Pendidikan: Dasar Teoritis Untuk Praktrek Profesional, (Bandung: Angkasa, 1993), hal. 301

Kartini kartono, Pemimpin dan Kepemimpinan, (Jakarta, RajaGrafindo Persada, 1993), hal. 31

Sarlito w. Sarwono, Pengantar Psikologi Umum, (Jakarta: Rajagrafindo Persada, 2009), hal. 225
} 
2. Robert Tanembaum, Pemimpin adalah mereka yang menggunakan wewenang formal untuk mengorganisasikan, mengarahkan, mengontrol para bawahan yang bertanggung jawab, supaya semua bagian pekerjaan dikoordinasi demi mencapai tujuan perusahaan.

3. Prof. Maccoby, Pemimpin pertama-tama harus seorang yang mampu menumbuhkan dan mengembangkan segala yang terbaik dalam diri para bawahannya. Pemimpin yang baik untuk masa kini adalah orang yang religius, dalam artian menerima kepercayaan etnis dan moral dari berbagai agama secara kumulatif, kendatipun ia sendiri mungkin menolak ketentuan gaib dan ide ketuhanan yang berlainan.

4. Lao Tzu, Pemimpin yang baik adalah seorang yang membantu mengembangkan orang lain, sehingga akhirnya mereka tidak lagi memerlukan pemimpinnya itu.

5. Davis and Filley, Pemimpin adalah seseorang yang menduduki suatu posisi manajemen atau seseorang yang melakukan suatu pekerjaan memimpin.

6. Sedangkan didalam Pancasila, Pemimpin harus bersikap sebagai pengasuhyang mendorong, menuntun, dan membimbingasuhannya. Dengan kata lain, beberapa asas utama dari kepemimpinan Pancasila adalah $:^{7}$

a. Ing Ngarsa Sung Tuladha: Pemimpin harus mampu dengan sifat dan perbuatannya menjadikan dirinya pola panutan dan ikutan bagi orang - orang yang dipimpinnya.

b. Ing Madya Mangun Karsa: Pemimpin harus mampu membangkitkan semangat berswakarsa dan berkreasi pada orang - orang yang dibimbingnya.

c. Tut Wuri Handayani: Pemimpin harus mampu mendorong orang - orang yang diasuhnya berani berjalan di depan dan sanggup bertanggung jawab.

Dari beberapa definisi diatas, dapat ditarik kesimpulan bahwa pemimpin

Kartini Kartono, Pemimpin Dan Kepemimpinan, ... hal. 284 
adalah pribadi yang memiliki sebuah kecakapan khusus, dengan atau tanpa pengangkatan resmi dapat mempengaruhi kelompok yang dipimpinnya, untuk melakukan usaha bersama mengarah pada pencapaian sasaran-sasaran tertentu.

Maksud dari "dengan atau tanpa pengangkatan "adalah bahwa pemimpin dibagi menjadi pemimpin formal dan pemimpin informal. ${ }^{8}$ Pemimpin formal adalah orang yang oleh lembaga/ organisasi tertentu ditunjuk sebagai pemimpin berdasarkan keputusan dan pengangkatan resmi memnagku suatu jabatan dalam struktur organisasi dengan segala hak dan kewajibannya. Sedangkan untuk pemimpin informal adalah orang yang tidak mendapatkan pengangkatan formal sebagai seorang pemimpin, tetapi karena keunggulanya dan kemampuannya dalam mempengaruhi orang lain,

Seorang pemimpin yang kompeten dan berkarismatik haruslah memilki tujuh karakteristik kunci sebagai berikut ini: ${ }^{9}$

1. percaya diri

2. memiliki visi,

3. memiliki kemampuan untuk mengartikulasikan visi,

4. memiliki pendirian yang kuat terhadap visinya,

5. memiliki perilaku yang berbeda dari kebiasaan orang,

6. merasa sebagai agen pembaru dan,

7. sensitif terhadap lingkungan

Dari uraian diatas, dapat disimpulkan perbedaan antara pemimpin dan kepemimpinan, walaupun mempunyai kaitan yang sangat erat sekali. Bahwa seorang pemimpin adalah pelaku, subyek yang berbentuk fisik, dan dapat dilihat, sedangkan kepemimpinan adalah kemampuan pemimpin, seni memimpin untuk mengatur, mempengaruhi orang. membina, memenej sebuah organisasi/ lembaga untuk mencapai tujuan tertentu.

Ibid. hlm. 9

Nurkolis, Manajemen Berbasis Sekolah, (Jakarta : Grasindo, 2003), hal. 157 


\section{Kepala Sekolah Sebagai Pemimpin}

Kepala sekolah berasal dari dua kata yaitu "Kepala" dan "Sekolah" kata kepala dapat diartikan ketua atau pemimpin dalam suatu organisasi atau sebuah lembaga. Sedang sekolah adalah sebuah lembaga dimana menjadi tempat menerima dan memberi pelajaran. Jadi secara umum kepala sekolah dapat diartikan pemimpin sekolah atau suatu lembaga di mana tempat menerima dan memberi pelajaran.

Wahjosumidjo mengartikan bahwa: "Kepala sekolah adalah seorang tenaga fungsional guru yang diberi tugas untuk memimpin suatu sekolah dimana diselenggarakan proses belajar mengajar, atau tempat dimana terjadi interaksi antara guru yang memberi pelajaran dan murid yang menerima pelajaran. Sementara Rahman dkk mengungkapkan bahwa "Kepala sekolah adalah seorang guru (jabatan fungsional) yang diangkat untuk menduduki jabatan struktural (kepala sekolah) di sekolah”.

Berdasarkan beberapa pengertian di atas dapat disimpulkan bahwa kepala sekolah adalah sorang guru yang mempunyai kemampuan untuk memimpin segala sumber daya yang ada pada suatu sekolah sehingga dapat digunakan secara maksimal untuk mencapai tujuan.

Kepala Sekolah sebagai pemimpin harus mampu memberikan petunjuk dan pengawasan guna meningkatkan kemampuan tenaga kependidikan. Untuk memenuhi hal tersebut, maka kepala sekolah haruslah mempunyai kompetensi. Setidaknya kepala sekolah perlu mempunyai kompetensi sebagai berikut: ${ }^{10}$

1. Mefasilitasi pengembangan, penyebarluasan, dan pelaksanaan visi pembelajar yang dikomunikasikan dengan baik dan didukung oleh komunitas sekolah.

2. Membantu, membina, dan mempertahankan lingkungan sekolah dan program pengajaran yang kondusif bagi proses belajar peserta didik dan pertumbuhan professional para guru dan staf.

10 Mulyono, ukuran kepala sekolah yang kompeten. (Jurnal kependidikan dan kemasyarakatan, cendekia, Ponorogo, 2012), hal. 236 
3. Menjamin bahwa manajemen organisasi dan pengoperasian sumber daya sekolah digunakan untuk menciptakan lingkungan belajar yang aman, sehat, efisien, dan efektif.

4. Bekerjasama dengan orang tua murid dan anggota masyarakat, menanggapi kepentingan dan kebutuhan komunitas yang beragam, dan memobilisasi sumber daya masyarakat

5. Memberi contoh/teladan tindakan berintegritas

6. Memahami, menanggapi, dan mempenggaruhi lingkungan politik, social, ekonomi, dan budaya yang lebih luas

Kepala sekolah adalah penggerak utama daripada sebuah sekolah yang dipimpinya. Maju atau tidaknya sebuah sekolah terletak pada kepemimpinan kepala sekolah. Maka dari itu, Dinas pendidikan menetapkan bahwa kepala sekolah harus mampu melaksanakan pekerjaanya sebagai edukator, manajer, administrator, supervisior, leader, innovator, dan motivator. ${ }^{11}$

1. Kepala sekolah sebagai edukator: dalam hal ini kepala sekolah harus memiliki strategi yang tepat dalam meningkatkan keprofesionalismenya di sekolah. Kepala sekolah harus berusaha menanamkan, memajukan dan meningkatkan sedikitanya empat macam nilai, yakni pembinaan mental, moral, fisik, dan artistik.

2. Kepala sekolah sebagai manajer: sebagai manajer, kepala sekolah harus mampu dan mau mendayagunakan visi, misi dalam mencapai tujuan, kepala sekolah harus mampu bekerja melalui orang lain, seta mau mempertanggungjawabkan setiap tindakannya

3. Kepala sekolah sebagai administrator: kepala sekolah harus memiliki kemampuan untuk mengelola kurikulum, mengelola administrasi peserta didik, mengelola administrasi personalia, mengelola administrasi kearsipan, dan mengelola administrasi keuangan.

4. Kepala sekolah sebagai supervisior: kepala sekolah harus mampu melakukan berbagai pengawasan dan pengendalian untuk meningkatkan kinerja tenaga kependidikan.

11 E. mulyasa, Menjadi Kepala Sekolah Professional, (Bandung:Remaja Orsdakarya, 2004), hal. 98. 
5. Kepala sekolah sebagai leader: kepala sekolah sebagai leader harus mampu memberikan petunjuk dan pengawasan, meningkatkan komunikasi dua arah, dan mendelegasikan tugas

6. Kepala sekolah sebagai innovator: kepala sekolah sebagai innovator haruslah mempunyai strategi yang tepat untuk menjalin hubungan yang harmonis dengan lingkungan, mencari gagasan baru, mengintegrasikan setiap kegiatan, memberikan teladan kepada seluruh tenaga kependidikan di sekolah, dan mengembangkan model-model pembelajaran yang innovative.

7. Kepala sekolah sebagai motivator : sebagai motivator, kepala sekolah harus memiliki strategi yang tepat untuk memberikan motivasi kepada para tenaga kependidikan dalam melakukan berbagai tugas dan fungsinya. Motivasi ini dapat ditumbuhkan melalui pengaturan lingkungan fisik, pengaturan suasana kerja, disiplin, dorongan penghargaan seara efektif, dan penyediaan berbagai sumber belajar melalui pengembangan.

Kepala sekolah tidak hanya dituntut untuk melaksanakan berbagai tugasnya disekolah, tetapi ia juga harus mampu menjalain hubungan kerjasama dengan masyarakat dalam rangka membina pribadi peserta didik secara optimal, hal ini sangatlah penting karena banyak persoalan yang tidak dapat diselesaikan oleh sekolah secara sepihak, atau perbedaan persepsi, kesalahpahaman antara pihak sekolah dan masyarakat.

Kepala Sekolah dalam menjalankan tugasnya mempunyai beberapa Gaya Kepemimpinan. Menurut Purwanto gaya kepemimpinan dibagi menjadi 3 (tiga) yaitu sebagai berikut:

1. Kepemimpian yang otokratik

Dalam kepemimpinan yang otokratik, pemimpin bertindak sebagai diktator terhadap anggota-anggota kelompoknya. Baginya, memimpin adalah menggerakkan dan memaksa kelompok. Kekuasaan pemimpin yang otokratik hanya dibatasi oleh undang-undang penafsirannya sebagai pemimpin tidak lain adalah menunjukkan dan memberi perintah, kewajiban bawahan atau anggota-anggotanya hanyalah mengikuti dan menjalankan tidak boleh membantah ataupun memberikan saran. 
2. Kepemimpinan yang laissez faire

Dalam gaya kepemimpinan ini sebenarnya pemimpin tidak memberikan pimpinan. Gaya ini diartikan sebagai membiarkan orang-orang berbuat sekehendaknya. Pemimpin yang termasuk gaya ini sama sekali tidak memberikan kontrol dan koreksi terhadap pekerjaan anggota anggotanya. Pembagian tugas dan kerja sama diserahkan kepada anggotaanggota kelompoknya., tanpa petunjuk atau saran-saran dari pimpinan. Kekuasaan dan tanggung jawab simpang siur berserakan diantara anggota-anggota kelompok, tidak merata.

3. Kepemimpinan Yang Demokratis

Pemimpin yang memilikigaya demokratis menafsirkan kepemimpinannya bukan sebagai diktator, melainkan sebagai pemimpin di tengah-tengah anggota kelompoknya. Hubungan dengan anggota-anggota kelompok bukan sebagai majikan terhadap buruhnya, melainkan sebagai saudara tua di antara teman-teman sekerjanya, atau sebagai kakak terhadap saudara-saudaranya. Pemimpin yang demokratis selalu berusaha menstimulasi anggota-anggotanya agar bekerja secara kooperatif untuk mencapai tujuan bersama. Dalam tindakan dan usaha-usahanya, ia selalu berpangkal pada kepentingan dan kebutuhan kelompoknya dan mempertimbangkan kesanggupan serta kemampuan kelompoknya. ${ }^{12}$

\section{Penerapan Kepemimpinan di SD IT Salsabila 3 Banguntapan}

\section{A. Kepala Sekolah sebagai Pemimpin}

Kedudukan kepala sekolah adalah pemimpin tertinggi dan harus membawahi, mengayomi semua sumber daya manusia di sekolah tersebut. Dalam peran ini, kepala sekolah adalah penanggung jawab terhadap pelaksanaan keseluruhan proses pendidikan di sekolah yang dilakukan oleh seluruh unsur warga sekolah. Sebagai seorang pemimpin, wajar jika kepala sekolah dituntut untuk mengupayakan pelaksanaan proses pendidikan secara efektif dan efisien. Kemajuan suatu sekolah sangat ditentukan oleh

12 Purwanto Ngalim. 2008. Administrasi dan Supervisi Pendidikan. (PT Remaja Rosdakarya: Bandung, 2008) Hal.48-52 
kepemimpinan kepala sekolah, hal ini bisa diibaratkan "kepala sekolah adalah nahkoda kapal ditengah lautan lepas, keberhasilan kapal mencapai tujuan tergantung nahkoda kapal tersebut membawanya."

Berdasarkan data yang diperoleh di lapangan, kepemimpinan kepala sekolah di SD IT Salsabila 3 Banguntapan adalah sebagai berikut:

1. Tugas dan tanggung jawab merupakan sesuatu hal yang harus dilaksanakan oleh kepala sekolah dalam memangku jabatan. Kepala sekolah adalah pemimpin pendidikan yang memiliki peranan sangat besar dalam mengembangkan mutu pendidikan di sekolah. Berkembangnya semangat kerja, kerjasama yang harmonis, minat terhadap perkembangan pendidikan, suasana kerja yang menyenangkan dan perkembangan mutu profesional diantara para guru, banyak ditentukan oleh kualitas dan gaya kepemimpinan kepala sekolah. Kepala sekolah SD IT Salsabila 3 dalam mengupayakan tercapainya tujuan menerapkan gaya demokratis, hal ini terbukti kepala sekolah selalu melibatkan steakholder dalam pembuatan kebijakan sekolah. Kepala sekolah selalu bermusyawarah dan meminta pendapat dalam melaksanakan programnya. Dalam meminta pendapat bawahannya kepala sekolah biasanya mengadakan rapat koordinasi dengan para waka. Tidak hanya dalam membuat kebijakan saja kepala sekolah melakukan musyawarah, namun juga pada saat menerapkan suatu kebijakan, kepala sekolah terlebih dahulu bermusyawarah dengan para bawahannya. Setiap lembaga pendidikan pada dasarnya untuk menarik perhatian masyarakat pasti memiliki ciri khas tertentu/ keunggulan tertentu agar dapat bersaing dengan lembaga pendidikan yang lainnya.

2. Kepala sekolah SD IT Salsabila 3 Banguntapan mempunyai beberapa peranan, diantaranya yaitu:

a. Kepala Sekolah sebagai edukator

Kepala sekolah SD IT Salsabila 3 Banguntapan sebagai educator (pendidik) adalah orang yang mendidik, memberikan latihan (ajaran, pimpinan) mengenai akhlak maupun kecerdasan pikiran. Kepala sekolah dalam mendidik menerapkan metode keteladanan dan pembiasaan. Hal ini merupakan salah satu metode yang sangat penting dalam membentuk karakter baik peserta didik, guru maupun pegawai. 
b. Kepala sekolah sebagai administrator

Kepala sekolah SD IT Salsabila 3 Banguntapan telah mampu menguasai tugas-tugasnya dan melaksanakan tugasnya dengan baik. Hal ini dikarenakan kepala sekolah kreatif serta memiliki ideide dan inisiatif yang mampu menunjang perkembangan sekolah. Perencanaan untuk mengembangkan sekolah telah dibuatnya, seperti program tahunan sekolah. Selain perencanaan kepala sekolah juga memahami pengelolaan administrasi yang bersifat pencatatan dan pendokumentasian seluruh program sekolah. Kepala sekolah dituntut memahami dan mengelola kurikulum, administrasi peserta didik, administrasi sarana dan prasarana, dan administrasi kearsipan.

Mengenai Administrasi kurikulum Kepala sekolah didampingi waka kurikulum membuat kebijakan kurikulum SD IT Salsabila 3 Banguntapan sedemikian rupa, yaitu secara dokumentasi memang mengikuti Dinas akan tetapi secara prakteknya untuk mapel agama jumlah JPL ditambah dari volume seharusnya khususnya jam mengaji, kepala sekolah berasumsi siswa yang mempunyai hafalan bagus pasti mudah dalam mengikuti mapel-mapel yang diajarkan di sekolah. Berdasarkan pengalaman yang siswa yang telah mempunyai hafalan lebih dari yang sisiwa lainnya merupakan siswa yang berpresatsi di bidang akademik juga.

Pada tahun ini fokus utama pengembangan ditujukan akan pengadaan dan melengakapi sarana dan prasarana sekolah. Dalam hal ini kepala sekolah mengalami beberapa kendala, diantaranya adalah terkait terbatasnya dana. Kepala sekolah SD IT Salsabila 3 dalam mengelola administrasi keuangan sudah baik, hal ini terbukti kepala sekolah sudah transparan dalam membahas administrasi keuangan sekolah.

c. Kepala sekolah sebagai leader, innovator, manager, supervisor

SD IT Salsabila 3 Banguntapan merupakan sekolah dasar yang memiliki ciri khas tertentu/ menurut kami keunggulan tertentu. Ciri khas SD IT Salsabila 3 Banguntapan ini terletak pada suasana Qur'ani yang diterpakan oleh pihak lembaga sekolah. Pihak-Pihak 
yang terlibat dalam pengembangan SD ini sangat mendukung akan adanya suasana Sekolah Qur'ani.

1) Kebijakan kepala sekolah kepada peserta didik

Kepala sekolah juga menetapkan bahwasanya dalam proses sehari-hari kegiatan para peserta didik untuk didorong untuk menciptakan suasana Qurani ${ }^{13}$. Hal ini Dapat dilihat jadwal yang telah disusun oleh kurikulum yaitu dari jam 07.00-08.00 WIB para peserta didik ditanamkan nilai-nilai spiritual. Mulai dari kegiatan sholat dzuha sampai membaca/ menghafal alQur'an, setelah itu di akhir pelajaran pada jam 13.35-14.30 dilaksanakan kegiatan Baca Tulis Al-Quran, Review (hafalan al-quran dan mata pelajaran). Dalam proses pembelajaran di sekolah SD IT ini memang seakan-akan tidak sesuai dengan standar pemerintah dalam proses belajar mengajar untuk tingkatan SD, dan SD IT ini dalam pelaksanaanya memiliki hidden kurikulum atau bisa disebut juga dengan misi kurikulum tersembunyi. Akan tetapi dalam proses pelaporan ke lembaga pendidikan, SD IT ini sesuai dengan standar pelaksanaan kegiatan belajar mengajar.

Kegiatan yang mendukung terciptanya suasana Qurani ialah kegiatan pada setiap malem jumat. Pada malam ini para peserta didik melaksanakan kegiatan kegiatan doa bersama atau biasa disebut dengan Mujahadah bersama sampai pukul 21.00. kegitan ini diikuti oleh seluruh guru dan karyawan beserta murid dari kelas 4 SD- 6 SD.

2) Kebijakan Kepala sekolah terhadap tenaga pendidik dan kependidikan

Dalam rangka menerapkan kebijakan khususnya tentang kedisiplinan pendidik dan tenaga kependidikan kepala sekolah SD IT Salsabila Banguntapan sebagai pemimpin memantau rekap kehadiran. Jika terdapat pegawai yang tidak disiplin

13 Yang dimaksud "suasana qurani" adalah proses kegiatan para peserta didik dalam membaca, Menulis dan menghafal al-Quran. 
maka langkah pertama yang membina adalah para waka dan dilanjutkan oleh kepala sekolah. Bila dalam pemantauan tidak ada perubahan barulah kepala sekolah memberikan SP 1. Pemberian SP 1 diberikan dengan terus memantau kinerja pendidik tersebut. Bila belum ada perubahan barulah SP 2 dan selama SP 2 belum ada perubahan kearah yang lebih baik, kepala sekolah bertindak tegas yaitu dengan mengkoordinasi dengan yayasan. Hasil koordinasi itulah yang nantinya akan diterapkan kepada yang bersangkutan, bisa dimutasi ataupun diberhentikan.

Mengenai sanksi yang diberikan kepada guru maupun pegawai berdasarkan tingkatannya, apakah itu pelanggaran berat, sedang atau ringan. Pelanggaran berat seperti pelanggaran susila, pelanggaran yang mempengaruhi integritas guru, indisipliner sedangkan yang termasuk kategori sedang itu seperti terlambatnya tugas guru atau sedikit mengabaikan ini, kepala sekolah memberikan pembinaan secara wajar, hal ini dikarenakan guru belum mengasai kompetensinya, seperti telatnya pengumpulan RPP. Berkaitan dengan hal ini kepala sekolah memberikan wewenang kepada waka kurikulum untuk memberikan layanan terhadap administrasinya.

Berdasarkan data hasil wawancara, kepala sekolah memberikan pembinaan kepada seluruh tenaga pendidik dan kependidikan setiap 1 minggu sekali (daurah). Pada agenda daurah mingguan kepala sekolah mempunyai kesempatan untuk melakukan pembinaan serta mengevaluasi seperti tentang penurunan tingkat kedisiplinan. Selain pembinaan mingguan, khusus untuk pendidik juga diadakan pembinaan bulanan, akan tetapi hal ini terjadi di yayasan. Untuk tingkat unit dilaksanakan pada minggu ke-2 dan ke-3 disinilah peranan kepala sekolah sebagai supervisior sekaligus evaluator. Pada minggu ke-4 kepala sekolah bersama guru dan karyawan mengadakan agenda pengajian rutinan keluarga SD IT 3 
Salsabila Banguntapan. Adanya kegitan ini terciptalah ramah tamah antara anggota satu dengan yang lainnya. Ini merupakan pengajian yang mengarahkan kepada hubungan yang harmonis.

Adanya kekurangan cakapan guru dalam membuat perangkatadministrasi maupun menggunakan sarana dan media merupakan kendala bagi kepala sekolah sebagai supervisor. Hal ini tentunya menjadikan adanya hambatan bagi kepala sekolah untuk melakukan supervise kelas saat guru mengajar. Adanya kekurangan disiplinan dari guru maupun pegawai juga merupakan kendala, karena untuk memajukan suatu lembaga organisasi hal yang paling penting adalah kedisiplinan. Untuk mengatasi maslah kedisiplinan seperti dijelaskan di atas, kepala sekolah melakukan pembinaan baik terhadap guru, maupun pegawai.

d. Kepala sekolah sebagai Motivator

Kepala sekolah selaku pemberi motivasi guru dan pegawai supaya bekerja dengan sungguh-sungguh, maka kepala sekolah harus memberikan dorongan yang tinggi. Upaya meningkatkan kinerja dan tanggung jawab pendidik, kepala sekolah memberikan reward kepada guru berprestasi. Tentunya hal ini menjadikan para pendidik berlomba-lomba untuk menjadi sosok guru berprestasi. Adanya kepala sekolah memberikan penghargaan kepada guru yang paling disiplin maupun berprestasi ada daya tarik tersendiri bagi para guru. Pemberian penghargaan dilakukan pada event "Hari Guru".

Pemberian reward ada yang diberikan secara incidental dan rutin. Untuk pemberian reward incidental diberikan ketika guru mendapatkan prestasi dalam lomba atau berprestasi dalam kegiatan tertentu. Pemberian reward rutin itu diberikan karena adanya akumulasi yang diperoleh kepala sekolah selama memonitoring guru selama satu tahun. hasil monitoring dari kepala sekolah akan mendapatkan guru yang mempunyai dedikasi tinggi. Pemberian reward rutin inilah yang diberikan pada event hari guru. 
Selain dengan memberikan penghargaan, kepala sekolah juga memberikan teladan kepada guru dengan melakukan dan memberikan contoh. Uniknya dalam hal ini kepala sekolah tidak bekerja sendirian melainkan para waka dan koordinator bidangpun harus ikut memberikan teladan, sehingga para guru ada upaya mencotohnya. Karena keteladanan dari kepala sekolah memang sangat diperlukan oleh para guru.

\section{E. Penutup}

Kepala Sekolah SD IT Salsabila 3 Banguntapan, dalam menjalankan tugasnya menggunakan system demokrasi. Kepala sekolah selalu menerapkan musyawarah baik dalam menentukan kebijakan, menerapkan kebijakan maupun pada saat menyelesaikan suatu permasalahan yang terjadi di sekolah. Kepala sekolah tidak bekerja sendiri dalam menjalankan tugas dan tanggung jawabnya melainkan melibatkan bawahanya dalam membuat atau menentukan kebijakan sekolah.

Kepala Sekolah SD IT 3 Salsabila 3 Banguntapan mempunyai peran yang sangat penting untuk meningkatkan kinerja guru diantaranya yaitu: 1. Educator, 2. Leader, 3. Manager, 4. Motivator, 5. Supervisor, 6. Innovator, dan 7. Administrator. Ke-tujuh peranan tersebut telah dilaksanakan oleh kepala sekolah SD IT 3 Salsabila Banguntapan. Dengan adanya peranan yang demikian menjadikan SD IT 3 Salsabila termasuk sebagai sekolah yang lebih berprestasi dari pada sekolah lainnya.

\section{Daftar Pustaka}

Wahyudi, 2009, Kepemimpinan Kepala Sekolah:Dalam Organisasi Pembelajar, Bandung: Alfabeta.

Sutisna, Oteng, 1993, Administrasi Pendidikan: Dasar Teoritis Untuk Praktrek Profesional, Bandung: Angkasa

Kartono, Kartini, 1993, Pemimpin dan Kepemimpinan, Jakarta, RajaGrafindo Persada 
Sarwono, Sarlito w. 2009, Pengantar Psikologi Umum, Jakarta: Rajagrafindo Persada.

Nurkolis, 2003, Manajemen Berbasis Sekolah,Jakarta : Grasindo

Mulyono, 2012, Ukuran Kepala Sekolah yang Kompeten. Jurnal Kependidikan dan Kemasyarakatan, Cendekia, Ponorogo

E. Mulyasa, 2004, Menjadi Kepala Sekolah Professional, Bandung: Remaja Orsdakarya

Ngalim, Purwanto, 2008. Administrasi dan Supervisi Pendidikan. PT Remaja Rosdakarya: Bandung, 2008

Zamroni. 1992. Pengantar Pengembangan Teori Sosial. Yogyakarta: Tiara Wacana.

Bungin, Burhan. 2008. Penelitian Kualitatif: Komunikasi, Ekonomi, Kebijakan Publik, dan Ilmu Sosial Lainnya. Jakarta: Kencana. 